\title{
Two Patagonian basins - Negro (Argentina) and Valdivia (Chile) - as habitats for Plecoptera ${ }^{1}$
}

\author{
I.R. Wais ${ }^{2}$
}

Even though the insects of the Neotropical area had been neglected, several authors have studied different aspects of the Southern Neotropical Plecoptera (Aubert, Benedetto, Enderlein, Froehlich, Gerstaecker, Illies, Navás, Klapálek, Wer. ner, $\mathrm{Z}$ wick), specially the Andean oligostenothermal cool-adapted stoneflies.

Most of the Argentinian river basins are widely spread out. The upper reaches of the Negro hydrographic system are on the east slope of the Andes and discharge into the Limay and Neuquen rivers downstream. The Negro river is formed by the convergence of both rivers and presents a sequence of reservoirs (main-stream impoundments on Limay and offchannel ones at Neuquén); it reaches the South Atlantic coast at approximately $41^{\circ} \mathrm{S}$.

The headstreams of the Valdivia system are on the west slope of the Andes. This river, much shorter than the Negro, joins the Pacific at $40^{\circ} \mathrm{S}$. Transition from rhithron to potamon is rapid, if indeed the potamon exists.

Macrozoobenthic samples of these two North Patagonian river basins, Negro (Argentina) and Valdivia (Chile) were taken in the period 1977-1983 in order to compare habitats of aquatic insects and other invertebrates on both slopes of the Andes and at the same latitude.

Ten genera of Plecoptera were recorded by the author as nymphs : Gripopterygidae (Antarctoperla, Limnoperla, Pota. moperia, Pelurgoperla, and Araucanioperla?), Diamphipnoidae (Diamphipnoa and Diamphipnopsis), Austroperlidae (Klapopteryx), Notonemouridae (Austronemoura) and Perlidae (Kempnyella).

Most of these genera of Plecoptera were collected in the upper rhithral. Only Antarctoperla and Limnoperla were found in reservoirs, in one lake and in medium-size to wide rivers. Gripoperygids were more frequent on the Argentine side : the other families were more abondant on the opposite slope; this situation can probably be explained by the different ecological conditions brought about by catte raising and dam construction.

Dos cuencas patogónicas - Negro (Argentina) y Valdivia (Chile) - como hábitats para Plecópteros.

Aunque los insectos de la región neotropical han sido descuidados, algunos autores han estudiado diferentes aspectos acerca de los plecópteros del sud de América del Sur (Aubert, Benedetto, Enderlein, Froehlich, Gerstaecker, Illies, Navás, Klapálek, Werner, Zwick), especialmente los géneros oligoestenotérmicos adaptados a las aguas frias.

La mayor parte de las hoyas hidrográficas de Argentina ocupan una vasta extensión. Los arroyos y rios de cabecera de la cuenca del rio Negro se hallan en la ladera oriental de los Andes, descargando sus aguas en los grandes rios Limay y Neuquen, cuya convergencia forma el Negro. Hay una secuencia de embalses construidos, en construcción y programados sobre y fuera del curso pricipal del río en el Limay y Neuquén respectivamente. El r. Negro alcanza el Océano Atlán. tico Sur a los $41^{\circ} \mathrm{S}$ aproximadamente.

El sistema del Valdivia recoge las aguas de la ladera occidental de los Andes. Este río, mucho más corto que el Negro, alcanza el Pacífico a los $40^{\circ} \mathrm{S}$. La transición de ritrón a potamón es rápida, en caso de que se acepte la existencia de un potamón.

En el periodo 1977-1983 se tomaron muestras de macrozoobentos en estas dos hoyas norpatagónicas, Negro (Argentina) y Valdivia (Chile), con el fin de comparar los hábitats de los insectos acuáticos y otros invertebrados a ambos lados de los Andes a la misma latitud.

Se colectaron diez gèneros de Plecoptera como ninfas : Gripopterygidae (Antarctoperla, Limnoperla, Potamoperla, Pelurgoperla y Araucanioperla?), Diamphipnoidae (Diamphipnoa y Diamphipnopsis), Austroperlidae (Klapopteryx), Notonemou. ridae (Austronemoura) y Perlidae (Kempnyella).

1. Participation supported by the Organization of American States and the MAB/UNESCO Program.

2. Museo Argentino de Ciencias Naturales a B. Rivadavia * Instituto Nacional de Investigación de las Ciencas Naturales, Av. A. Gallardo 470, CC 220 Suc. 5, 1405 Buenos Aires, Argentina. 
La mayoría de estos géneros de Plecoptera se colectaron en ritrones altos. Sólo Antarctoperla y Limnoperla fueron encontrados en embalses, en un lago y en ríos medianos a anchos. Los Gripopterigidos fueron más abundantes del lado argentino y las otras familias fueron más frecuentes del lado chileno, probablemente debido a las diferentes condiciones ecológicas producidas por la presencia de ganado y la construcción de presas.

\section{Les Plécoptères de deux bassins patagoniens - Negro (Argentine) et Valdivia (Chili).}

Bien que les insectes de la région néotropicale ajent été négligés, quelques auteurs ont étudié différents aspects concernant les Plécoptères d'Amérique du Sud (Aubert, Benedetto, Enderlein, Froehlich. Gerstaecker, Illies, Navás, Klapálek, Werner, Zwick), spécialement les genres oligo-sténothermes adaptés à l'eau froide.

La plupart des bassins hydrographiques d'Argentine occupent une grande surface. Les ruisselets et ruisseaux de la partie supérieure du bassin du fleuve Negro se trouvent sur le flanc oriental des Andes et se déversent dans les grands fleuves Limay et Neuquén dont la confluence forme le Negro. Il y a une succession de réservoirs construits, en construction ou programmés, sur et hors du cours principal du fleuve, dans le Limay et le Neuquén. Le fleuve Negro se jette dans l'Océan Atlantique Sud à $41^{\circ} \mathrm{S}$ environ.

Le systeme du Valdivia recueille les eaux du flanc occidental des Andes. Ce fleuve, beaucoup plus court que le Negro. se jette dans le Pacifique à $40^{\circ} \mathrm{S}$. La transition du rhithron au potamon est rapide, si l'on accepte l'existence d'un potamon.

Dans la période 1977-1983, des récoltes de macrozoobenthos ont été faites dans ces deux bassins hydrographiques nordpatagoniens, Negro (Argentine) et Valdivia (Chili), afin de comparer les habitats des insectes aquatiques et des autres invertébrés des deux côtés des Andes à la même latitude.

On a récolté dix genres de Plécoptères à l'état de larves : Gripopterygidae (Antarctoperla, Limnoperla, Potamoperla, Pelurgoperla et Araucanioperla ?), Diamphipnoidae (Diamphipnoa et Diamphipnopsis), Austroperlidae (Klapopteryx), Notonemouridae (Austronemoura) et Perlidae (Kempnyella).

La plupart de ces genres de Plécoptères ont été trouvés dans des ruisseaux d'altitude. Seuls l'Antarctoperla et la Limnoperla ont été récoltees dans des réservoirs, dans un lac et dans de larges fleuves. Les Gripoptérygidés sont plus fréquents du côté argentin, tandis que les autres familles sont plus abondantes du cóté chilien, probablement à cause de conditions écologiques différentes produites par la présence de bétail et par les activités de construction de barrages.

\section{Introduction}

Hydrographic basins in Southern Southamerica have been incompletely studied and knowledge of their invertebrates is limited. Most macrobenthic organisms are immature stages of aquatic insects. Larvae, pupae, nymphs and even adults are still undescribed, and some families (Diptera : Simuliidae, Tabanidae, Culicidae ; Coleoptera : Gyrinidae, Hydrophilidae, Elmidae; Trichoptera : Hydropsychidae, Sericostomatidae, Leptoceridae, Glossosomatidae ; Odonata : Aeshnidae, Libellulidae, Coenagrionidae ; Plecoptera : Gripopterygidae, Diamphipnoidae, Austroperlidae, Perlidae; Ephemeroptera : Leptophlebiidae: Heteroptera: Notonectidae, Corixidae) have received more attention by taxonomists than others (Diptera : Muscidae (Limnophorinae), Athericidae, Stratyiomiidae, Ceratopogonidae, Chironomidae, Psychodidae, Tipulidae, Blephariceridae ; Coleoptera : Psephenidae ; Trichoptera : Lim- nephilidae, Calamoceratidae, Ryacophilidae; Plecoptera : Notonemouridae ; Ephemeroptera : Baetidae, Siphlonuridae).

Even though the insects of the Neotropical region have been neglected, fortunately several authors have studied different aspects of the Plecoptera fauna of Southern South America (Aubert, Benedetto, Enderlein, Froehlich, Gerstaecker, Illies, Navás, Klapálek, Werner, Zwick) ; among the papers that include studies on the Andean oligostenothermal cool-adapted stoneflies are those of Froehlich (1960) and Illies (1960a, 1960b, 1961, 1963, 1964, 1969).

Macrozoobenthos samples from two North Patagonian river basins, Negro (Argentina) and Valdivia (Chile), were collected in 1977-1983 in order to compare habitats of aquatic insects and other invertebrates on both slopes of the Andes at the same latitudes. The distribution of Plecoptera on each slope will be discussed below. 


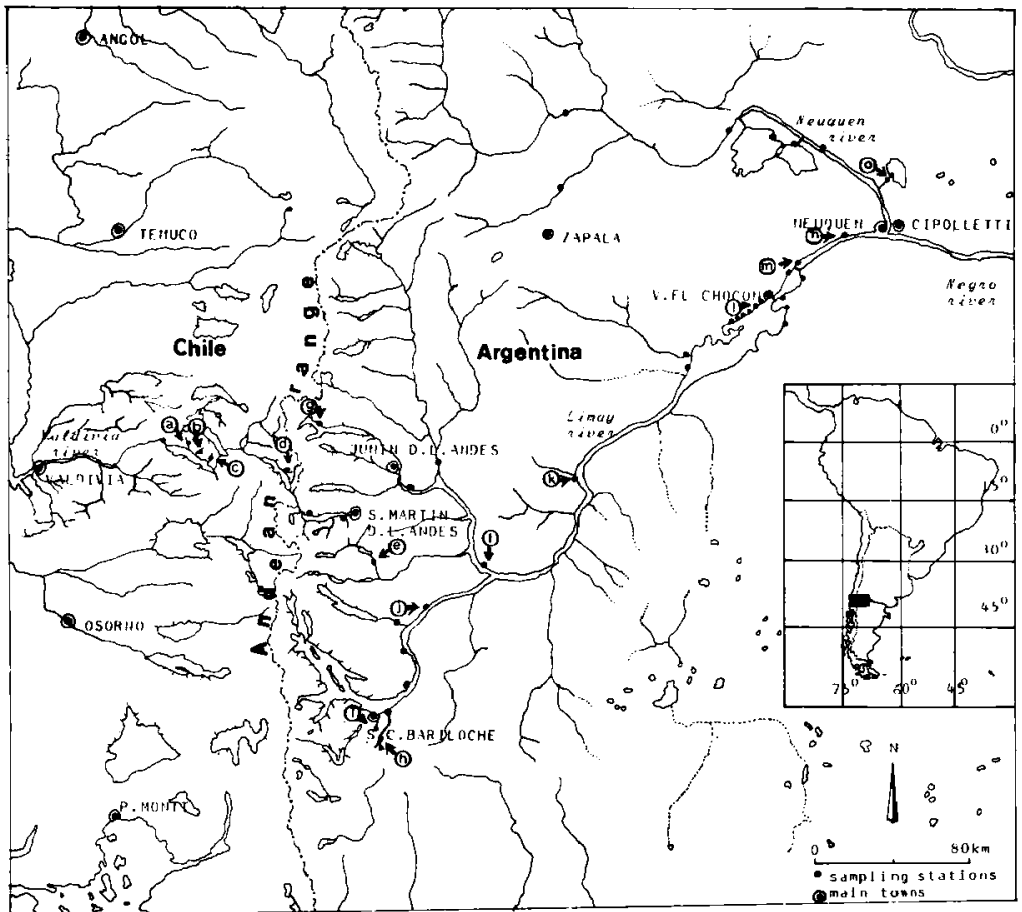

Fig. 1. Macrozoobenthos sampling stations on the Negro and Valdivia basins on 1977.1983. The arrows show the sites whe re Plecoptera nymphs were found. Distances between stations $a, b$ and $c$ are exagerated on the map for a clearer representation.

\section{Methodology}

Most of the samples were obtained on the Argentine side (1977-1982), as part of an ecological study of the river Negro basin (Wais 1983); some were also gathered in Chilean streams of the Valdivia system (1983). Sampling stations are indicated on Fig. 1. Macrozoobenthos has been collected with a modified Allen and Macan net and by hand. They were fixed in $4 \%$ tormalin and preserved in $70^{\circ}$ alcohol.

\section{Negro and Valdivia hydrographic basins}

Most Argentine river basins are spread out and cover large drainage areas. They originate from two main sources: the Andes and the Brazilian Cent ral Plateau. Chilean rivers are much shorter and drain generally from East to West, from either the main range of the Andes or the Coast Cordillera. 
The river Negro hydrographic basin lies between approximately $36^{\circ} .42^{\circ} \mathrm{S}$ and $62^{\circ} 30^{\prime}-71^{\circ} \mathrm{W}$. The upper limits of this system reach the Andean East slope, discharging in the Limay and Neuquén rivers downstream. The flow of the Limay is the most important ; it drains an area of $36400 \mathrm{~km}^{2}$ and it is the effluent of the glacial lake Nahuel Huapi. The Collón Curá river is its main tributary. The dis. charge rate of flow of the Limay is somewhat naturally regulated during floods by the many lakes in the catchment area : Aluminé, Norquincó, Quillén, Tromen, Huechulafquen, Currhué, Lolog, Hermoso, Meliquina, Falkner, Espejo, Nahuel Huapi (Fig. 1). The nearby Neuquén river, by contrast, has practically no lakes and unpredictable sudden floods are common.

Consecutive to the damming of the Limay (1972) for hydroelectric purposes, the Ramos Mexía main stream impoundment has been formed and its level is regulated by a compensator dam at Arroyito, downstream. Since 1914, the excess flow of the Neu- quén river is sent into an off-channel closed basin, forming the so-called "Pellegrini lake". More recently (1972) two huge impoundments have been constructed upstream: Los Barreales and Mari Menuco, as part of a hydroelectric program and also for flood control purposes. In the future, there actually would be a sequence of reservoirs (main stream impoundments on the Limay and off-channel ones on the Neuquén). The whole Limay river from Nahuel Huapi to Arroyito would be a chain of artificial lakes : Ramos Mexía (formed by El Clocón dam) and its compensator, Arroyito, are already flooded (Fig. 1); Alicurá is under construction and four other are under study or being planned : $\mathrm{Col}$ lón Curá, Piedra del Aguila, Pichi Picun Leufu and Michihuao (Fig. 2). The Limay river joins the Neuquen downstream of the derivation to Mari Menuco and Los Barreales reservoirs (closed by Planicie Banderita and Compensator dams, Fig. 2) and they constitute the Negro river, which, after approximately $500 \mathrm{~km}$, reaches the South Atlantic coast at $41^{\circ} \mathrm{S}$, as a real potamon.

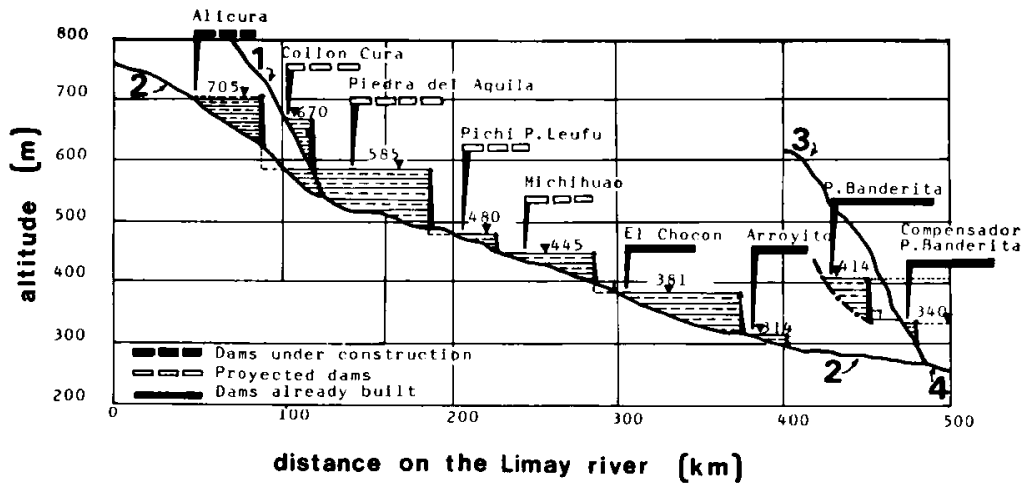

Fig. 2. Dams on the Negro basin. The large numbers refer to the main rivers : 1 - Collon Cura ; 2 - Limay : 3 . Neuquén : 4 - Negro (Modified from the data of Hidronor S.A.). 
Both the rivers Limay and Neuquén have a pluvionival regime, with two maximum flows, one due to heavy winter rains and the other in spring from ice and snow melt on the Andes. The mean discharge rates are $726 \mathrm{~m}^{3} \mathrm{~s}^{-1}$ for the Limay and $296 \mathrm{~m}^{3} \mathrm{~s}^{-1}$ for the Neuquén (data from Hidroeléctrica Norpatagónica S.A.). The annual precipitation decreases dramatically from the Cordillera to the East, and the area where the impoundments are located has semiarid characteristics (ap. $160 \mathrm{~mm}$ annual rainfall). The thermal amplitude of the Limay river increases downstream from Nahuel Huapi lake until it reaches the Ramos Mexia impoundment.

The waters of the system are well oxygenated, neutral and soft (Land de Castello 1981). Dissolved oxygen values are always near saturation and carbon dioxide concentrations are generally below $2 \mathrm{mg} \mathrm{l}^{-1}$.

The Valdivia river basin lies between approximately $39^{\circ} 30^{\prime}-40^{\circ} \mathrm{S}$ and $71^{\circ}-73^{\circ} 30^{\prime} \mathrm{W}$. The headstreams are on the West Andean slope. Its characteristics are similar to those of the upper part of Limay and its affluents. The Valdivia river flows freely through forested and agricultural lands and there are no $\mathrm{dam}^{3}$ in its basin and no semiarid region as on the Argentine slope. Assuming that a real potamon exists, the transition from rhithron to potamon is sudden. Otherwise, the hyporhithron would reach the ocean coast. The presence of potamon in the Chilean basins is actually disputed (Campos 1983, pers. com.).

Valdivia river is the effluent of five important glacial lakes : Lacar, Pirihueico, Calafquén, Panguipulli and Rinihue, interconnected by means of short rivers; Rinihue is the lowest of them and its catch. ment area is approximately $4290 \mathrm{~km}^{2}$ (Campos et al. 1978). All the lakes effluents flow into it : Rinihue then empties in to the Pacific Ocean at almost $40^{\circ} \mathrm{S}$ through the short $(110 \mathrm{~km})$ river San Pedro, named Calle Calle downstream, and finally Valdivia after receiving the river Cruces. The last $15 \mathrm{kilo}$ meters show estuarine characteristics. The Valdivia river has a mean freshwater discharge of $1000 \mathrm{~m}^{3} \mathrm{~s}^{-1}$ (Campos et al. 1974).

3. except a dam on the short Huanehue river, next to the small Pullingue lake, between the more important Colafquen and Panguipulli lakes. The deviation is less than $7 \mathbf{~ k m}$ long and the effects of this construction are local.

\section{Plecoptera of Negro and Valdivia basins}

The Northpatagonian zone is rich in endemics and poor in number of species (Noodt 1962, Di Castri 1968, Fittkau 1969. Campos et al. 1974). Indeed, the Plecoptera are a fairly old group of insects of running freshwater with an extremely high degree of endemic evolution in the mountains of the Southern Southamerica (Illies 1977).

There are six families of Plecoptera recorded from the area of the Negro and Valdivia basins (Benedetto 1974, Illies 1977): Perlidae (3 genera, Illies 1964), Notonemouridae (4 gen.), Eusteniidae (2 gen.), Diamphipnoidae ( 2 gen.), Gripopterygidae (16 gen.) and Austroperlidae (2 gen.); total number of genera : 29 , according to the distribution mentionned by Benedetto (1974).

From the samples taken at 43 stations on the Negro and Valdivia basins, 10 genera of Plecoptera belonging to 5 different families have been collected as nymphs, but only at 15 stations. As the principal subject of the study was the composition and ecology of the benthic fauna, no collection of adults was carried out. The sampling stations where stoneflies were found are:

Chile : a) Nancul river : b) Triu-Triu creek, $100 \mathrm{~m}$ upstream from the discharge into lake Rinihue ; $c)$ creek w/n, $200 \mathrm{~m}$ from its drainage into the Rinihue, next to the Lab. of Zool. Inst., Austral Univ. ; d) creek w/n. immediately upstream from the discharge into lake Pirihueico, next to Puerto Fuy.

Argentina : e) Meliquina river ; f) Collón Curá river ; g) Huechulafquen lake ; h) Ñirihuau river ; i) Nireco river; j) Limay river, at Alicurá ; k) Limay river, at Bajada Colorada ; 1) Ramos Mexia reservoir, at Boca de Sapo; m) Limay river, downstream Arroyito dam; n) Limay river, at Plottier; o) Pellegrini impoundment.

The ten genera collected belong : one to the Perlidae, one to the Notonemouridae, two to the Diamphipnoidae, five to the Gripopterygidae and one to the Austroperlidae (Table I).

\section{Discussion}

Not all the genera recorded before in this zone (mainly collected more than twenty years ago) have 
Table I. - Genera of Plecoptera collected during 1977-1983 on the Negro and Valdivia basins. Descriptions of sampling stations in the text.

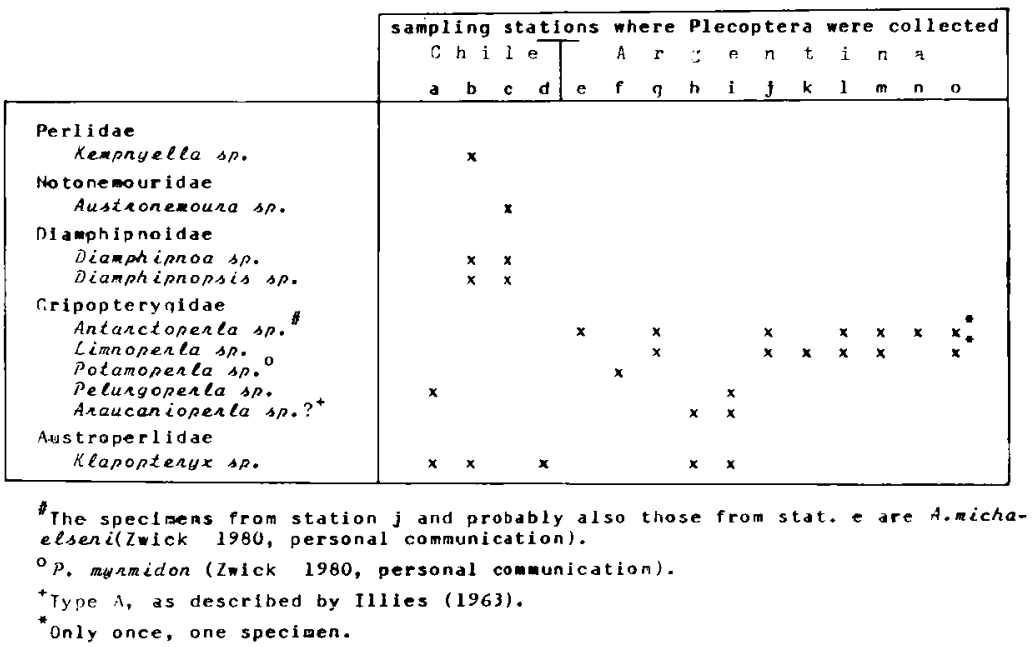

been found by the author, probably because not enough high headstreams, where most of the stonefly species live, were sampled. Considering the quite large drainage areas of the basins, no collection of macrozoobenthos was carried out in the numerous mountain creeks. But even though the sampling efforts were not directed to an adequate survey of headstreams, a decrease of the number of species may well have been produced by the environmental changes of the last years in the area.

All the ten genera collected between 1977-1983 belong to high, cold, well oxygenated rhithrons, corresponding to creeks and small to medium-sized rivers. Only Antarctoperla and Limnoperla seem to have wider ecological ranges, because they occur also in reservoirs, in one lake and in wide rivers (Limay downstream Arroyito dam and at Plottier, table I). Gripopterygids were more abundant on the Argentine slope ; the other families, on the Chilean slope.
Although Valdivia and the upper reaches of Limay system are similar in their main hydromorphological characteristics, the distinct distributions we recorded for several families of Plecoptera, which occurred before on both slopes of the Andean range, reflect now a net preference for one slope or the other; this may be explained by the particular conditions which exist on each side of the Cordillera as observed at the sampling stations. Despite the fact that in the Argentine slope of the Andes there are two important National Parks, Nahuel Huapi and Lanin, there is partial disturbance by cattle grazing. This activity, produced by native settlers, increased over the last years. The creeks studied showed evidence of the presence of cows, horses and goats. The cattle raising exists but is much less developped on the Chilean slope. Some genera of stoneflies are probably sensitive to slight alterations of the water quality and do not survive. This would not be the case of the Gripopterygids. It is not possible to genera- 
lize about the "tolerance of a family", since each species has a different ecological niche, but as a first approximation, Gripopterygids may be better adapted to bear environmental alterations within certain limits.

Another disturbance is being caused by the intense soil removal on the Limay river in relation with dam constructions, which affects water and substrate quality in the river and in the lower part of its affluents, specially at Alicurá and in the surrounding areas. Adult aquatic insects, under these ecological conditions, may be laying their eggs in other places, within the range of their limited flight capacity.

Stoneflies are seriously affected by changing water and substrate quality : they are good indicators of environmental alterations even at the generic level, as was demonstrated for the Northern hemisphere (Baumann 1979). We may draw as a preliminary conclusion, in a similar way, that cattle grazing on the headwater areas and dam construction downstream, probably disturb the macrobenthos community of those rhithrons, and specially the stoneflies.

More studies should be done on the Southern Neotropical endernic area. In particular efforts should be made to find the relationships between the different chemical and physical parameters and the habitats requirements of the stonefly larvae as has been reported for the Northern hemisphere fauna by Surdick \& Gaufin (1978).

\section{Acknowledgements}

To the Hidroeléct rica Norpatagónica S.A., Argentina, to the Administración de Parques Nacionales, Argentina, and to the Instituto de Zoología de la Universidad Austral, Chile, who provided assistance, permission to sample, field excursions, and laboratory space ; to Dr. H.H. Campos, Dr. A.O. Bachmann and Dr. A.A. Bonetto for their advice : to Lic. H.P. Castello for the criticism on the original manuscript : to Dr. P. Zwick for his assistance in identifying some genera and to Dr. R.W. Baumann for increasing my interest in Plecoptera.

\section{Literature clted}

Baumann (R.W.). 1979. - Neartic stonefly genera as indicators of ecological parameters (Plecoptera : Insecta). Greal Basin Nat., 39 (3): $241-244$.

Benedet to (L.). 1974. - Key for the identification of South American Plecoptera. Stud. Neotr. Fauna, 9 : 141-170 (in Spanish. summary in English).

Campos (H.H.). Bucarey (E.) \& Arenas (J.N.). 1974. - Limnological studies of lake Riñihue and Valdivia river (Chile). Bol. SocBiol Concepción $48: 47-67$ (in Spanish, abstract in English).

Campos (H.H.), Arenas (J.N.), Steffen (W.) \& Agüero (G.). 1978 Physical and chemical limnology of lake Riñihue (Valdivia, Chile). Arch. Hydrobiol., 84 (4) : $405-429$

Di Castri (F,) 1968. - Esquisse écologique du Chili. Biol de l'Amerique Australe, $4: 7-60$

Fittkau (E). 1969 . - The fauna of South America. In : Biogeography and Ecology in South America, 2. 624-658.

Froehlich (C.). 1960. - Some Gripopterygids and Notonemourines (Plecoptera) from South America. Lunds Univ. Ȧrsskr. (NF 2), $56(13): 1-23$.

Illies (J.). 1960 a. - Archiperlaria, eine neue Unterordnung der Plecopteren (Revision der Familien Eustheniidae und Diamphiproidae). Beitr. Ent., 10:061-697.

fllies (J.) $1960 \mathrm{~b}$. - Penturoperlidae, eine neue Plecopterenfamilie. Zool. Anz., $164(1 / 2): 26-41$.

Illies (J.). 1961. - Südamerikanische Notonemourinae un die Stellung der Unterfamilie im System der Plecopteren. Mitt. schweiz, ent. Ges., 34 (2) : 97-126.

Illies (J.). 1963. - Revision der südamerikanischen Gripopterygidae. Mitt. schweiz. ent. Ges., 36 : 145-248.

Illies (J.) 1964 - Südamerikanische Perlidae (Plecoptera), besonders aus Chile und Argentinien. Beirr. neotr. Fauna, 3 (3): 207-233.

Illies (J.). 1969. - Revision der Plecopterenfamilie Aust roperlidae. Entomol. Ts. Arg., 90 : 19-51.

Illies (J.). 1977. - Plecoptera. In : Biota Acuática de Sudamérica Austral, San Diego St. Univ. Press, 185-186.

Land de Castello (H.B.). 1981. - Some abjutic limnological aspects of the Limay and Neuquen river basins, with special reference to the Ramos Mexia reservoir. Ecosur, 16 (8) : 1-27 (in Spanish. summary in English).

Noodt (W.). 1962. - Uber Tiera rmut in Chile. Zcol. Anz, Suppl. 25 433-437.

Surdick (R.F.) \& Gaufin (A.R.). 1978. - Environmental requirements and pollution tolerance of Plecoptera. U.S. Environ. Pro tect. Agency Rep. 600/4-78-062: 1-417.

Wais (I.R.). 1983. - Macroinvertebrates of creeks, rivers and lakes of the Argentine Northpatagonia. V. Chilean Workshop on Lim nology held at Oromo, Chile on Jan. 19 to 21 (in Spanish).

Zwick (P). 1973. - Insecta : Plecoptera. Phylogenetesches System und Katalog. Das Tierreich, $94: 1.32+1.465$. 